\title{
"Packaging Logistics" for improving performance in supply chains: the role of meta-standards implementation
}

\author{
Jesús García-Arca ${ }^{\mathrm{a} *}$, Alicia Trinidad González-Portela Garrido ${ }^{\mathrm{b**}}$, José Carlos Prado-Prado ${ }^{\mathrm{a} * * *}$ \\ alndustrial Engineering School, University of Vigo, Vigo, Spain

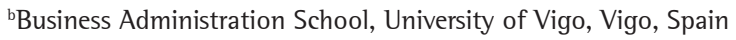 \\ *jgarca@uvigo.es, **tgonzalez-portela@uvigo.es, ${ }^{* * *}$ jcprado@uvigo.es
}

\begin{abstract}
Integrated packaging design process arises as one key factor that could contribute to increasing the efficiency and sustainability of supply chains. This approach is called "packaging logistics". Another managerial approach that is related to efficiency and sustainability is the implementation of "meta-standards" (ISO 9000 and $1 S 0$ 14000). As both "packaging logistics" and "meta-standards" can contribute positively towards supply chain efficiency and sustainability, it becomes relevant to examine the relationship between them. In this study, we explore the potential relation between "meta-standards" (ISO 9000 and ISO 14000) and the implementation of the key aspects of "packaging logistics". In addition, we explore the relation between "packaging logistics" and aspects of performance. This is accomplished through an exploratory study of the packaging design process of Spanish manufacturers in the food industry.
\end{abstract}

Keywords

Packaging. Supply chain. Logistics. ISO 9000. ISO 14000.

\section{Introduction}

Nowadays, supply chain executives should increase efforts to improve competitiveness and sustainability by eliminating activities that do not add value and by developing innovations in processes and products (Christopher, 2005; Andersen \& Skjoett-Larsen, 2009; García-Arca et al., 2011). Simultaneously, different "stakeholders" show a growing interest in the sustainability of supply chains (Seuring \& Müller, 2008; Andersen \& Skjoett-Larsen, 2009). Seuring \& Müller (2008) show the potential outcomes from developing a sustainable supply chain in terms of environmental, economic and social development: it saves resources, reduces waste, and provides competitive advantages.

Alongside this scenario of pursuing sustainability and efficiency throughout the supply chain, companies should develop actions that impact positively both strategic as well as operational aspects of the processes (framed in the logistic activities of supplying, production, physical distribution and reverse logistics). Past research (e.g., Saghir \& Jönson, 2001; Klevas, 2005; Hellström \& Saghir, 2006; Verghese \& Lewis, 2007; García-Arca \& Prado-Prado, 2008a; Azzi et al., 2012; García-Arca et al., 2014) consider packaging as one of the key and global elements that support an efficient and sustainable supply chain. These authors show that supply chain companies have different requirements with regard to packaging. Such requirements are not distributed homogeneously in the different levels of packaging (primary, secondary and tertiary levels), and require that packaging, logistics, and product aspects be integrated.

This context has led to the development of the concept of "packaging logistics". Saghir (2004, p. 6) presents the concept of Packaging Logistics as 
[...] the process of planning, implementing and controlling the coordinated packaging system of pre-paring goods for safe, secure, efficient and effective handling, transport, distribution, storage, retailing, consumption and recovery, reuse or disposal and related information combined with maximizing consumer value, sales and hence profit.

Going further, García-Arca et al. (2014, p. 330) propose a wider definition, introducing the concept of "sustainable packaging logistics" as

[...] the process of designing, implementing, and controlling the integrated packaging, product and supply chain systems in order to prepare goods for safe, secure, efficient and effective handling, transport, distribution, storage, retailing, consumption, recovery, reuse or disposal, and related information, with a view to maximizing social and consumer value, sales, and profit from a sustainable perspective, and on a continuous adaptation basis.

In the search for sustainability and efficiency, we have also seen increasing efforts to promote standardization in processes through the implementation of "meta-standards". Meta-standards are rules that ease the systematization of processes, thanks to the definition of procedures, instructions and records from a quality or environmental point of view (Heras-Saizarbitoria, 2011). The most well-known of these standards are the ISO 9001 Quality Management standard (International Organization for Standardization, 2015a; known as ISO 9000) and the ISO 14001 Environmental Management standard (International Organization for Standardization, 2015b; known as ISO 14000). Although the meta-standards have been widely adopted in different companies and sectors, empirical studies disagree over their impact on performance and financial results.

A number of critics argue that the extra documentation efforts required when implementing "meta-standards" are time-consuming, so adopting $1 \mathrm{SO}$ provides no real benefits for business performance (Aarts \& Vos, 2001; Terziovski et al., 2003). In this context, some research on the organizational impacts of ISO 9000 has suggested that ISO certification has little benefit in process efficiency, when combined with financial results (Terziovski et al., 2003; Castka \& Balzarova, 2008; Lo et al., 2009). In contrast, other authors argue that these standards can help a company bring about a much-needed critical rethinking of traditional practices (Castka \& Balzarova, 2008; Lo et al., 2009). Poksinska et al. (2003) summarize benefits stemming from ISO 9000 and ISO 14000, including relational benefits (improved relations with communities and authorities), external marketing benefits (improved corporate image, increased market share, increased customer satisfaction, increased on-time delivery), and internal performance benefits (cost reductions, environmental/quality improvements or increased productivity).

More recently, Prajogo et al. (2012) demonstrated that the advanced implementation of ISO 9000 positively affects some operational indicators in supply chain management. However, the basic implementation of ISO 9000 has no direct influence on these indicators. In general, literature seems to suggest that supply chain processes can become more efficient and sustainable, due to the ensuing standardization and systematization, when companies along the chain adopt "meta-standards". As both packaging logistics and "meta-standards" can contribute positively towards supply chain efficiency and sustainability, and "meta-standards" can facilitate the competitiveness of business processes, it becomes relevant to examine the relationship between them.

In this study, we explore the potential relation between meta-standards and the implementation of key aspects of packaging logistics. In addition, we explore the relation between packaging logistics and aspects of performance. As, to the best of our knowledge, such relations have not been studied before, to examine them we conduct an exploratory and descriptive study of the packaging design process of Spanish manufacturers in the food industry.

The subsequent sections of the manuscript are organized as follows. First, the conceptual and applied basis of the approach "packaging logistics" (or "sustainable packaging logistics") resulting from the literature review is developed and justified. Next we present our exploratory empirical analysis and then discuss the results. Finally, we conclude the study with recommendations for future studies.

\section{Developing a "Packaging Logistics" approach}

The sustainable improvement of supply chain management, both within each company and between companies in the chain, is one of the issues that have raised great interest among researchers, because it can be considered a source of competitive advantage (Christopher, 2005; Crnkovic et al., 2008; Germain et al., 2008; García-Arca et al., 2011).

Although an increasing number of companies, especially multinational companies, are making a decisive commitment to implementing sustainability and efficiency-oriented practices in their supply chains, the majority view continues to be that implementing sustainability strategies throughout the chain involves a certain incompatibility with the search for logistic 
efficiency (Andersen \& Skjoett-Larsen, 2009). As such, from a strategic point of view, there has been difficulties to make visible the relationship between supply chain management and sustainability.

In this context, packaging appears among the key elements that can support the implementation of efficiency and sustainability-oriented strategies. Beyond the traditional and basic view of packaging as a means of protecting products (Williams et al., 2008; Verghese et al., 2015), over the last few years, new design requirements have been added for packaging: on the one hand, to improve the differentiation capacity of the product (commercial function), and on the other, to improve the efficiency of the product at a logistic and production level (logistic function).

Likewise, this efficiency of packaging in logistics should be considered not only in terms of logistics (in the processes of supplying, packing, handling, storing, and transport), but also in environmental terms (the reduction of packaging and raw materials consumption; for example, re-use, recycle and/or recovery waste from packaging) (Grönman et al, 2013). In practice, this has led to the introduction of specific legislations (e.g., European Directive 94/62/EC; 1994 and its updated version 2004/12/EC) and has introduced the environmental function of sustainability into packaging design (European Commission, 1994, 2004).

Authors such as Saghir \& Jönson (2001), García-Arca \& Prado-Prado (2008a, b) and Bramklev (2009) identify three main functions in packaging: the commercial function, the logistics function and the environmental function. In order to put these functions into practice, it is essential to consider packaging as a system comprising three levels (Hellström \& Saghir, 2006): primary or consumer packaging, secondary or transport packaging (usually, boxes) and tertiary packaging (several primary or secondary packages grouped together on a pallet).

When considering packaging from a global perspective, the interaction among different levels and functions becomes clear, when depicting the interdependence among them. This is the key point relating to a global vision of packaging design and the main focus of "packaging logistics" or indeed "sustainable packaging logistics".

The selection of the "best packaging" is usually linked to considerations involving cost reduction. Thus, packaging design affects both direct costs (purchasing and waste management) and indirect costs (packing, handling, storage, transport and losses). It is precisely these indirect costs that impede an adequate understanding of the impact of certain decisions in packaging design (García-Arca \& Prado-Prado, 2008a). To illustrate the potential contribution to reducing overall costs, we can show some examples and figures:

- There are some studies estimating that 30-50\% of the world food is lost to waste. One action that could aid to decreasing waste in the food chain is packaging (Sohrabpour et al., 2012).

- A study of more than 300 companies in the supply chain of the Spanish food industry, shows that logistics costs (direct or indirect) due to packaging were approximately $40 \%$ of packing companies' revenue (14\% direct and 26\% indirect), and 10\% of distributors' revenue (García-Arca \& Prado-Prado, 2008b).

- This percentage of distributors' costs does not include the logistic costs at the point of sale. Some studies calculate the handling cost at the point of sale to be $10 \%$ of the product's price (Saghir \& Jönson, 2001).

- Approximately 9\% of the cost of any product is likely to be the cost of its packaging. Likewise, hidden costs associated with over-packaging in Europe, seem to be 20 times higher than the cost of excessive packaging materials (Azzi et al., 2012).

- The configuration of palletized unit loads affects the costs of physical distribution (handling, storage and transport). In this sense, at least $18 \%$ of pallets employed downstream in the supply chain were inefficient in terms of volume and/or weight (García-Arca \& Prado-Prado, 2008b).

- A study on retail markets, carried out in five European countries, points out that the wasted volume between the primary and secondary packaging varied between $34 \%$ and $50 \%$. Between the secondary packaging, which is usually a box, and the pallets, the unoccupied space varies between 46\% and 64\% (European Organization for Packaging and the Environment, 2009).

- A study carried out by P\&G found that between $2 \%$ and 10\% of products (depending on country and category) ended up damaged. Analysis of causes revealed a variety of issues in warehouse procedures, transportation and store handling methods that led to damage. However, a further analysis of the main causes of these damaged products highlighted that selected packaging was unsuitable for the supply chain (Van Hoek \& Chapman, 2006).

- The Swedish company IKEA has estimated that to carry 10\% more items per $\mathrm{m}^{3}$ would imply annual savings in its global supply chain of between 300 and 400 million euros. 
However, this cost reduction approach can be hazardous, if not considered in an integrated manner. While an "economic" packaging would be linked to a standard format with an appropriate, tried, and tested logistic efficiency, there may exist the need to make compromises to be "different" and sustainable. In practice, this means that packaging design demands some analysis of the "trade-offs" between the different functions from a supply chain perspective, and also a measurement system for evaluating packaging alternatives. For instance, introducing a protective function in packaging could be partially measured in economic terms by the cost of damaged products. However, it would be more difficult to measure the dissatisfaction that these damaged products generate along the supply chain, from the manufacturers to customers.

A similar difficulty is found when trying to measure the environmental costs of different packaging alternatives. Although some of these costs can be partially measured, such as Green Dot or returnable packaging systems (Mollenkopf et al., 2005), other costs are not so easily measured. This situation has led to the development of the "Life Cycle Assessment (LCA)" technique, the most commonly used system for measuring environmental impact in packaging design (Svanes et al., 2010; Azzi et al., 2012; Albrecht et al., 2013; Grönman et al., 2013).

To overcome these problems in analysis of packaging alternatives, different assessment models have been developed to deal with the difficulties in objectively evaluating each packaging alternative from a multifunctional perspective. The most well-known of these models is Olsmats and Dominic's "Packaging Scorecard" (2003). With this broader view of packaging the integration of logistics and packaging design has been conceptualized in the term "packaging logistics" (and "sustainable packaging logistics"), particularly emphasizing the operational and organizational repercussions (Hellström \& Saghir, 2006; García-Arca \& Prado-Prado, 2008a). Thanks to "packaging logistics" implementation, it is possible to deal with the search for packaging alternatives by combining the packaging structure and the four main decisions to be taken in design: the selection of materials, dimensions, groupings (the number of packs/package) and "graphic artwork" or the aesthetic design of packaging.

According to proposals by García-Arca \& Prado-Prado (2008a) and García-Arca et al. (2014, 2015), four key aspects could be identified in order to promote the development and implementation of 'Packaging Logistics':
- The definition of design requirements, based on identifying commercial, logistic, and environmental needs (Saghir \& Jönson, 2001; Bramklev, 2009). Going further, Azzi et al. (2012) proposes a wider combination of different design requirements/functions, including commercial, productive, logistic, purchasing and environmental functions.

- The definition of an organisational structure which integrates and coordinates all related areas along the supply chain, both internally in each company and externally, such as packaging manufacturers, distributors, third party logistics etc. The importance of these organizational aspects throughout the supply chain has been highlighted by authors such as Lee \& Lye (2003), Klevas (2005), Chan et al. (2006), Sohrabpour et al. (2012) and Molina-Besch \& Pålsson (2014).

- The definition of a system that measures and values the pros and cons of each alterative in packaging. Thus, it would be possible to evaluate different alternatives combining the packaging structure and the four main design decisions (Olsmats \& Dominic, 2003; Mollenkopf et al., 2005; Svanes et al., 2010; Azzi et al., 2012; Albrecht et al., 2013; Pålsson et al., 2013; Wever \& Vogtländer, 2013; Accorsi et al., 2014; Gamez-Alban et al., 2014; Dominic et al., 2015; Faccio et al., 2015).

- The adoption of "best practices"' and/or innovations in packaging design with a view to eliminating waste in the supply chain (Kye et al., 2013).

With regard to adopting "best practices" in the retail market, García-Arca \& Prado-Prado (2008a, b) have compiled a set of new approaches that could potentially generate improvements in the efficiency and/or overall sustainability of the supply chain. Some of these "best practices" affect the performance of the packaging design process: the documentation and systematization of the packaging design process, the documentation of the characteristics of materials used in packaging manufacturing, the documentation of the palletization patterns, and the use of computer tools to aid packaging design. However, other "best practices" could offer some efficient alternatives by themselves, although not necessarily the best ones. Among these "best practices" are:

- The standardization of formats and qualities in packaging; this action allows companies to improve efficiency in purchasing and packing processes.

- The implementation of efficient unit loads in the handling, storage and transport processes throughout the supply chain. In Spain, the characteristics of efficient pallets are summed up in the "AECOC Recommendations for logistics. Efficient Unit Loads" (RALs) (Asociación Española de Codificación 
Comercial, 2012). These RALs propose a series of packaging recommendations, with the objective of improving the efficiency in the logistic activities (handling, warehousing and transport). Among these recommendations are the use of EUR pallets, the definition of maximum height and weight of pallets and the promotion of modularity of packaging dimensions according to the module $600 * 400 \mathrm{~mm}$.

- The reduction of the raw materials used in packaging manufacturing, and of packaging waste. This target could imply the development of a specific plan for reducing the consumption and waste in packaging.

The description of the four key aspects of "packaging logistics" are summarized in Table 1. These key aspects will be considered later in the empirical study.

\section{Empirical analysis}

In this study, we explore the potential relation between meta-standards (ISO 9000 and ISO 14000) and the implementation of key aspects of "packaging logistics". In addition, we explore the relation between packaging logistics and aspects of performance. To achieve these goals, we explore the potential relationship between the existence of meta-standards in a company and the extent of the implementation of the packaging logistics approach, indicated by the presence of the defining key aspects of the practice summarized in the Table 1.

We carried out an exploratory study of the packaging design process in Spanish food companies (see Table 2). The authors selected food manufacturers, because of their level of competition and importance in the retail supply chain. The retail supply chain

Table 1. Research items related to "packaging logistics" implementation.

\begin{tabular}{|c|c|c|}
\hline Type of analysis & General Questions & Specific aspects in questions \\
\hline $\begin{array}{l}\text { A.- Packaging Design requirements } \\
\text { (Saghir \& Jönson, 2001; Bramklev, } \\
\text { 2009; Azzi et al., 2012) }\end{array}$ & $\begin{array}{l}\text { What level of importance } \\
\text { does the company give } \\
\text { to each of the packaging } \\
\text { functions during the } \\
\text { packaging design process? } \\
\text { (Likert scale) }\end{array}$ & $\begin{array}{l}\text { Protective function } \\
\text { Commercial function (product differentiation) } \\
\text { Productive function (packing process) } \\
\text { Logistic function (handling, storage and transport processes) } \\
\text { Purchasing and supplies function } \\
\text { Environmental function (minimizing consumption of raw materials } \\
\text { and generation of packaging waste) }\end{array}$ \\
\hline $\begin{array}{l}\text { B.- Organizational structure for } \\
\text { packaging design (internally in each } \\
\text { company and externally throughout } \\
\text { the supply chain) (Lee \& Lye, 2003; } \\
\text { Klevas, 2005; Chan et al., 2006; } \\
\text { Sohrabpour et al., 2012; Molina-Besch } \\
\text { \& Pålsson, 2014) }\end{array}$ & $\begin{array}{l}\text { In your company, what level } \\
\text { of coordination is achieved, } \\
\text { internally and externally, } \\
\text { in order to integrate } \\
\text { the different design } \\
\text { requirements in a more } \\
\text { efficient and sustainable } \\
\text { packaging? (Likert scale) }\end{array}$ & $\begin{array}{l}\text { Level of internal coordination in packaging design } \\
\text { Level of coordination with packaging suppliers in packaging design } \\
\text { Level of coordination with clients and/or distributors in packaging } \\
\text { design }\end{array}$ \\
\hline $\begin{array}{l}\text { C.- Evaluation system in packaging } \\
\text { design (Olsmats \& Dominic, } \\
\text { 2003; Mollenkopf et al., 2005; } \\
\text { Svanes et al., 2010; Azzi et al., 2012; } \\
\text { Albrecht et al., 2013; Grönman et al., } \\
\text { 2013; Pålsson et al., 2013; Wever } \\
\text { \& Vogtländer, 2013; Accorsi et al., } \\
\text { 2014; Gamez-Alban et al., 2014; } \\
\text { Dominic et al., 2015; Faccio et al., } \\
\text { 2015) }\end{array}$ & $\begin{array}{l}\text { Has your company adopted } \\
\text { a measurement system } \\
\text { for evaluating different } \\
\text { packaging alternatives from } \\
\text { a sustainable supply chain } \\
\text { perspective? (Yes/No) }\end{array}$ & $\begin{array}{l}\text { Implementation of "Packaging Scorecard" system } \\
\text { Implementation of LCA System }\end{array}$ \\
\hline \multirow{3}{*}{$\begin{array}{l}\text { D.- Adoption of "best practices" in the } \\
\text { packaging design process (García-Arca } \\
\text { \& Prado-Prado, 2008a, b; Asociación } \\
\text { Española de Codificación Comercial, } \\
\text { 2012; Kye et al., 2013) }\end{array}$} & $\begin{array}{l}\text { Has your company } \\
\text { implemented any of the } \\
\text { following actions for } \\
\text { systematizing packaging } \\
\text { design? (Yes/No) }\end{array}$ & $\begin{array}{l}\text { Documentation for the packaging design process } \\
\text { Documentation for the technical specifications in the formats and } \\
\text { qualities of materials used in the packaging } \\
\text { Documentation for the product palletization files } \\
\text { Use of computer tools in packaging design }\end{array}$ \\
\hline & $\begin{array}{l}\text { What level of } \\
\text { implementation does } \\
\text { your company have in } \\
\text { the adoption of actions } \\
\text { designed to improve logistics } \\
\text { efficiency? (Likert scale) }\end{array}$ & $\begin{array}{l}\text { Standardization of formats and qualities in packaging } \\
\text { Application of the "AECOC Recommendations for logistics" } \\
\text { (Efficient palletized loads) }\end{array}$ \\
\hline & $\begin{array}{l}\text { Has your company } \\
\text { implemented a plan to } \\
\text { improve environmental } \\
\text { behaviour in relation to } \\
\text { packaging design? (Yes/No) }\end{array}$ & $\begin{array}{l}\text { Plan for preventing packaging waste and reducing raw materials in } \\
\text { packaging manufacturing }\end{array}$ \\
\hline
\end{tabular}


is a good example of all packaging considerations previously mentioned and, as such, is conducive to explore the relations we are examining.

The data collection for this study was based on structured postal questionnaires featuring the questions presented in the Table 1. The interviewees in each company were mostly logistics or production managers. The selection of companies in the study was supported by the Alimarket data base (1,492 companies), one of the most representative sources of Spanish retail companies. The response rate was 13.94\%.

As shown in Table 1, most of the items were measured using a Likert scale varying from 1 to 5 (where 1 indicates a very low level of implementation and 5 a very high level of implementation). In order to compare and justify the potential contributions of meta-standard implementation, a Mann-Whitney U test was used to evaluate the company's responses. This is a nonparametric test to identify whether a particular population tends to have larger values than another. However, the level of implementation was not deemed appropriate for all the items in the study (for example, in the questions regarding measurement systems or the actions devoted to the systematization of the packaging design process). In this case, only two situations were considered: Yes or No. The authors used a Fisher Test (Pearson Chi-Square Test) based on contingencies tables in order to support the analysis of the potential impact of the meta-standards implementation on some type of questions.

Finally, in order to connect the deployment of "packaging logistics" with the improvement of competitiveness and sustainability, the companies were asked about the changes made in their packaging and how such changes have had an influence on different performance aspects, such as commercial differentiation, reducing costs (purchasing, production or logistic) or improving environmental behavior throughout the supply chain. In this last aspect, a Likert scale was again used, with 5 being very good results or very positive impact, and 1 being poor results or scarce impact.

The frequency to which meta-standards were implemented in the sample is presented in the Table 3. According to the descriptive measures, we found that the level of implementation of the 1SO 9000 series is high, while the implementation of the ISO 14000 series is much lower. In fact, most companies with ISO 14000 also have ISO 9000.

The main results are outlined below. These results are divided into five headings intended to explore whether firms that implement meta-standards are associated with higher levels of implementation of key aspects of 'packaging logistics'. We conclude examining packaging changes in terms of improved logistics efficiency and sustainability.

\subsection{Design requirements}

The study presents some interesting results regarding the potential impact involved in implementing the meta-standards. An increased importance is given to packaging design requirements at the development stage (see Table 4).

Table 4 indicates that companies with meta-standard practices (ISO 9000 and ISO 14000) seem to place higher importance on some aspects of packaging design requirements. Specifically, companies with ISO 9000 tend to focus more on the productive and logistics side of packaging design than companies that do not have 1509000 , while companies that have ISO 14000 tend to focus more on the productive and environmental sides of packing design than those that do not have ISO 14000. Companies with meta-standards in place do not seem to differ from those without them in terms of product protection, commercial, and purchasing sides of packaging design

Table 2. The technical file of the study.

\begin{tabular}{ll}
\multicolumn{1}{c}{ Universe: } & $\begin{array}{r}\text { Spanish manufacturers of food products with over } 6 \text { million Euros turnover. All companies distribute } \\
\text { their products with palletized loads (source: Alimarket data base) }\end{array}$ \\
\hline $\begin{array}{l}\text { Method of the collection of } \\
\text { information }\end{array}$ & $\begin{array}{l}\text { Postal technique with the support of a structured questionnaire } \\
\text { Size of the sample: }\end{array}$ \\
Valid questionnaires & 209 manufacturers (response rate $13.94 \%)$ \\
Sampling error: & $6.42 \%$ ( $p=q=0.5 ;$ Level of confidence $95.5 \%)$ \\
lnterviewee's profile & Logistics/production managers \\
\hline
\end{tabular}

Table 3. The implementation of ISO 9000 and 1S0 14000 standards in the sample.

\begin{tabular}{|c|c|c|c|c|c|}
\hline \multicolumn{2}{|c|}{ WITH ISO 9000} & \multicolumn{2}{|c|}{ WITH ISO 14000} & \multicolumn{2}{|c|}{ BOTH ISO 9000 and ISO 14000} \\
\hline Number of companies & $\%$ & Number of companies & $\%$ & Number of companies & $\%$ \\
\hline 131 & $62.67 \%$ & 40 & $19.13 \%$ & 39 & $18.66 \%$ \\
\hline
\end{tabular}


requirements. Interesting, focus on the productive aspect of packaging design seems common to firms with either one of the ISO standards when compared with firms without either ISO.

\subsection{Organizational structure}

We expected that greater sensitivity to meet the different packaging design requirements should go hand-in-hand with greater coordination, both at an internal, manufacturers level (among all the areas of departments affected in the design process), and at an external, supply chain level (with clients and packaging suppliers). Table 5 indicates that companies with meta-standard practices (ISO 9000 and ISO 14000) seem to place higher importance on the internal and upstream coordination. Specifically, companies with ISO 9000 tend to focus more on the internal coordination of packaging design than companies that do not have 1SO 9000 and on the coordination with suppliers as well (common to the firms with ISO 14000) than companies that do not have 150 in place.

\subsection{The measurement system for evaluating packaging alternatives}

From an environmental perspective, the number of companies with ISO 9000 that have implemented and standardized a system for comparing packaging alternatives, such as LCA, is low and does not tend to be different than that of companies that do not have ISO 9000. However, companies with ISO 14000 have implemented the LCA technique more often (see Table 6).

Table 4. The importance of packaging design requirements.

\begin{tabular}{|c|c|c|c|c|c|c|}
\hline & $\begin{array}{l}\text { Mean with } \\
\text { 1SO } 9000\end{array}$ & $\begin{array}{l}\text { Mean without } \\
\text { 1SO } 9000\end{array}$ & Statistic analysis & $\begin{array}{l}\text { Mean with } \\
\text { ISO } 14000\end{array}$ & $\begin{array}{l}\text { Mean without } \\
\text { ISO } 14000\end{array}$ & Statistic analysis \\
\hline $\begin{array}{l}\text { Product } \\
\text { protection }\end{array}$ & 4.31 & 4.28 & $\begin{array}{c}Z \text { Stat }=0.881 \\
P(T<=t)=0.379\end{array}$ & 4.22 & 4.32 & $\begin{array}{c}Z \text { Stat }=0.735 \\
P(T<=t)=0.462\end{array}$ \\
\hline Commercial & 3.9 & 4.08 & $\begin{array}{c}t \text { Stat }=0.800 \\
P(T<=t)=0.424\end{array}$ & 4.02 & 3.95 & $\begin{array}{c}Z \text { Stat }=0.474 \\
P(T<=t)=0.636\end{array}$ \\
\hline Productive & 3.89 & 3.51 & $\begin{aligned} \text { Z Stat } & =2.490 \\
P(T<=t) & =0.013^{* *}\end{aligned}$ & 4.05 & 3.68 & $\begin{aligned} \text { Z Stat } & =1.641 \\
P(T<=t) & =0.097 *\end{aligned}$ \\
\hline $\begin{array}{l}\text { Packaging } \\
\text { purchases }\end{array}$ & 3.679 & 3.49 & $\begin{array}{c}Z \text { Stat }=1.072 \\
P(T<=t)=0.284\end{array}$ & 3.8 & 3.55 & $\begin{array}{c}Z \text { Stat }=1.088 \\
P(T<=t)=0.277\end{array}$ \\
\hline Logistics & 3.67 & 3.35 & $\begin{aligned} \mathrm{Z} \text { Stat } & =1.720 \\
\mathrm{P}(\mathrm{T}<=\mathrm{t}) & =0.085 *\end{aligned}$ & 3.7 & 3.51 & $\begin{array}{c}Z \text { Stat }=0.924 \\
P(T<=t)=0.356\end{array}$ \\
\hline Environmental & 3.28 & 3.18 & $\begin{array}{c}Z \text { Stat }=0.510 \\
P(T<=t)=0.610\end{array}$ & 3.87 & 3.09 & $\begin{aligned} \text { Z Stat } & =3.298 \\
P(T<=t) & =0.01^{* * *}\end{aligned}$ \\
\hline
\end{tabular}

${ }^{*} \mathrm{P}<0.1$. ${ }^{* *} \mathrm{P}<0.05$. ${ }^{* * *} \mathrm{P}<0.01$.

Table 5. The internal and external coordination in packaging design.

\begin{tabular}{|c|c|c|c|c|c|c|}
\hline & $\begin{array}{l}\text { Mean with } \\
\text { 1SO } 9000\end{array}$ & $\begin{array}{l}\text { Mean without } \\
\text { 1SO } 9000\end{array}$ & Statistic analysis & $\begin{array}{l}\text { Mean with } \\
\text { ISO } 14000\end{array}$ & $\begin{array}{l}\text { Mean without } \\
\text { ISO } 14000\end{array}$ & Statistic analysis \\
\hline $\begin{array}{l}\text { Internal coordination } \\
\text { for packaging design }\end{array}$ & 3.80 & 3.36 & $\begin{aligned} \mathrm{Z} \text { Stat } & =2.363 \\
\mathrm{P}(\mathrm{T}<=\mathrm{t}) & =0.018^{* *}\end{aligned}$ & 3.67 & 3.63 & $\begin{array}{c}Z \text { Stat }=0.323 \\
P(T<=t)=0.747\end{array}$ \\
\hline $\begin{array}{l}\text { External } \\
\text { coordination with } \\
\text { clients/ distributors }\end{array}$ & 3.23 & 3.25 & $\begin{array}{c}Z \text { Stat }=0.287 \\
P(T<=t)=0.774\end{array}$ & 3.35 & 3.22 & $\begin{array}{c}t \text { Stat }=0.428 \\
P(T<=t)=0.669\end{array}$ \\
\hline $\begin{array}{l}\text { External } \\
\text { coordination with } \\
\text { packaging suppliers }\end{array}$ & 3.20 & 2.84 & $\begin{aligned} \mathrm{Z} \text { Stat } & =2.117 \\
\mathrm{P}(\mathrm{T}<=\mathrm{t}) & =0.034^{* *}\end{aligned}$ & 3.473 & 2.982 & $\begin{aligned} \text { Z Stat } & =2.137 \\
P(T<=t) & =0.033 \text { *** }\end{aligned}$ \\
\hline
\end{tabular}

Table 6. The implementation of sustainable "best practices" in packaging design ( $\%$ of companies with these systems implemented).

\begin{tabular}{|c|c|c|c|c|c|c|}
\hline & $\begin{array}{c}\text { \% of companies } \\
\text { with } 1509000 \\
\text { that said YES }\end{array}$ & $\begin{array}{c}\% \text { of companies } \\
\text { without } 1 S 09000 \\
\text { that said YES }\end{array}$ & Statistic analysis & $\begin{array}{l}\% \text { of companies } \\
\text { with } 1 S 014000 \\
\text { that said YES }\end{array}$ & $\begin{array}{c}\text { \% of companies } \\
\text { without } \\
\text { 1SO } 14000 \text { that } \\
\text { said YES }\end{array}$ & Statistic analysis \\
\hline $\begin{array}{l}\text { LCA } \\
\text { implementation } \\
\text { for comparing } \\
\text { packaging } \\
\text { alternatives }\end{array}$ & $12.97 \%$ & $12.82 \%$ & $\begin{array}{c}Z \text { Stat }=0.24 \\
P(T<=t)=0.528\end{array}$ & $26.47 \%$ & $11.92 \%$ & $\begin{aligned} \text { Z Stat } & =4.713 \\
P(T<=t) & =0.034^{* *}\end{aligned}$ \\
\hline
\end{tabular}


Curiously, our data indicates that no company in our sample has developed an integrated measurement system, such as the "Packaging Scorecard", to facilitate the comparison of different packaging alternatives from a perspective of supply chain efficiency.

\subsection{The "Best Practices" implementation in packaging design}

The Table 7 indicates that companies with meta-standards in general (ISO 9000 and ISO 14000) place greater importance on the various packaging design best practices outlined. The table also suggests that a considerable percentage of companies with ISO do focus on the best practices in general.

Less evident, although nonetheless positive, are the impacts in other "best practices", such as the application of the "AECOC Recommendations for logistics” (RALs) (see Table 8). We see that companies with 1SOs tend to focus more on RAL in packaging design than companies without the ISOs. However, no significant difference between companies with and without 1SOs has been found for the "best practices" related to improving management of purchases and supplies, such as the standardization of formats and qualities in packaging.

The Table 9 indicates that companies with meta-standard practices (ISO 9000 and ISO 14000) seem to place a higher importance on deploying prevention plans for reducing the packaging waste and the raw materials consumption than companies that do not have the 1SOs.

\subsection{The impact on supply chain efficiency and sustainability}

Lastly, we pay attention to the changes in packaging promoted by companies under analysis. We found that the most common changes developed by companies in the sample are the graphic arts, the packing process, and the standardization of packaging formats and qualities. The Table 10 shows that companies with ISO 9000 tend to benefit more from cost reduction in logistics and packaging than companies that

Table 7. The implementation of "best practices" for structuring packaging design.

\begin{tabular}{|c|c|c|c|c|c|c|}
\hline & $\begin{array}{c}\text { \% of companies } \\
\text { with } 1 S 09000 \\
\text { that said YES }\end{array}$ & $\begin{array}{c}\text { \% of companies } \\
\text { without } \\
\text { 1SO } 9000 \text { that } \\
\text { said YES }\end{array}$ & Statistic analysis & $\begin{array}{c}\text { \% of companies } \\
\text { with } 1 \mathrm{SO} 14000 \\
\text { that said YES }\end{array}$ & $\begin{array}{c}\text { \% of companies } \\
\text { without } 1 S 014000 \\
\text { that said YES }\end{array}$ & Statistic analysis \\
\hline $\begin{array}{l}\text { Availability of a } \\
\text { Packaging Design } \\
\text { Procedure }\end{array}$ & $41.98 \%$ & $20.51 \%$ & $\begin{aligned} \text { Z Stat } & =10.457 \\
P(T<=t) & =0.001^{* * *}\end{aligned}$ & $40 \%$ & $32.5 \%$ & $\begin{array}{c}Z \text { Stat }=0.869 \\
P(T<=t)=0.227\end{array}$ \\
\hline $\begin{array}{l}\text { Availability } \\
\text { of Technical } \\
\text { Specifications } \\
\text { of formats and } \\
\text { qualities in } \\
\text { packaging }\end{array}$ & $89.79 \%$ & $61.54 \%$ & $\begin{aligned} \text { Z Stat } & =18.780 \\
P(T<=t) & =0.000^{* * * *}\end{aligned}$ & $90 \%$ & $75.14 \%$ & $\begin{aligned} \text { Z Stat } & =4.185 \\
P(T<=t) & =0.028\end{aligned}$ \\
\hline $\begin{array}{l}\text { Availability of } \\
\text { Palletization Files }\end{array}$ & $86.51 \%$ & $55.40 \%$ & $\begin{aligned} \text { Z Stat } & =24.053 \\
P(T<=t) & =0.000^{* * *}\end{aligned}$ & $85 \%$ & $68.64 \%$ & $\begin{aligned} \text { Z Stat } & =3.833 \\
P(T<=t) & =0.035 \text { ** }\end{aligned}$ \\
\hline $\begin{array}{l}\text { Use of computer } \\
\text { tools in } \\
\text { packaging design }\end{array}$ & $34.35 \%$ & $26.92 \%$ & $\begin{array}{c}Z \text { Stat }=1.276 \\
P(T<=t)=0.166\end{array}$ & $52.5 \%$ & $26.62 \%$ & $\begin{array}{c}\text { Z Stat }=8.494 \\
P(T<=t)=0.004\end{array}$ \\
\hline
\end{tabular}

Table 8. The implementation of logistic "best practices" in the packaging design.

\begin{tabular}{|c|c|c|c|c|c|c|}
\hline & $\begin{array}{l}\text { Mean with } \\
\text { 1SO } 9000\end{array}$ & $\begin{array}{l}\text { Mean without } \\
\text { 1SO } 9000\end{array}$ & Statistic analysis & $\begin{array}{l}\text { Mean with } \\
\text { 1SO } 14000\end{array}$ & $\begin{array}{l}\text { Mean without } \\
\text { ISO } 14000\end{array}$ & Statistic analysis \\
\hline $\begin{array}{l}\text { Level of } \\
\text { lmplementation } \\
\text { of the RAL in } \\
\text { packaging design } \\
\text { (level) }\end{array}$ & 3.01 & 1.97 & $\begin{array}{c}\text { Z Stat }=3.904 \\
P(T<=t)=0.000^{* * * *}\end{array}$ & 3.37 & 2.5 & $\begin{array}{c}\text { Z Stat }=2.832 \\
P(T<=t)=0.005^{* * *}\end{array}$ \\
\hline $\begin{array}{l}\text { Level of } \\
\text { Standardization } \\
\text { of formats and } \\
\text { qualities in } \\
\text { packaging }\end{array}$ & 3.86 & 3.74 & $\begin{array}{c}Z \text { Stat }=0.686 \\
P(T<=t)=0.493\end{array}$ & 4.08 & 3.75 & $\begin{array}{c}Z \text { Stat }=1.220 \\
P(T<=t)=0.222\end{array}$ \\
\hline
\end{tabular}


Table 9. The implementation of sustainable "best practices" in packaging design.

\begin{tabular}{|c|c|c|c|c|c|c|}
\hline & $\begin{array}{c}\text { \% of companies } \\
\text { with } 1 S 09000 \\
\text { that said YES }\end{array}$ & $\begin{array}{c}\text { \% of companies } \\
\text { without } \\
\text { 1SO } 9000 \text { that } \\
\text { said YES }\end{array}$ & Statistic analysis & $\begin{array}{c}\% \text { of companies } \\
\text { with 1SO } 14000 \\
\text { that said YES }\end{array}$ & $\begin{array}{c}\% \text { of companies } \\
\text { without } \\
\text { 1SO } 14000 \text { that } \\
\text { said YES }\end{array}$ & Statistic analysis \\
\hline $\begin{array}{l}\text { Availability of a } \\
\text { Plan for preventing } \\
\text { packaging waste } \\
\text { and reducing } \\
\text { consumption of } \\
\text { raw materials in } \\
\text { packaging }\end{array}$ & $94.65 \%$ & $39.74 \%$ & $\begin{array}{c}\text { Z Stat }=9.083 \\
P(T<=t)=0.003^{* * *}\end{array}$ & $92.5 \%$ & $47.13 \%$ & $\begin{aligned} \text { Z Stat } & =26.673 \\
P(T<=t) & =0.000^{* * * *}\end{aligned}$ \\
\hline
\end{tabular}

Table 10. The impact of the packaging changes on logistic efficiency and sustainability.

\begin{tabular}{|c|c|c|c|c|c|c|}
\hline $\begin{array}{l}\text { Impact of the } \\
\text { packaging changes }\end{array}$ & $\begin{array}{l}\text { Mean with } \\
\text { 1SO } 9000\end{array}$ & $\begin{array}{l}\text { Mean without } \\
\text { 1SO } 9000\end{array}$ & Statistic analysis & $\begin{array}{l}\text { Mean with } \\
\text { 1SO } 14000\end{array}$ & $\begin{array}{l}\text { Mean without } \\
\text { ISO } 14000\end{array}$ & Statistic analysis \\
\hline $\begin{array}{l}\text { Differentiation } \\
\text { improvement }\end{array}$ & 3.748 & 3.819 & $\begin{array}{c}Z \text { Stat }=0.031 \\
P(T<=t)=0.975\end{array}$ & 3.692 & 3.794 & $\begin{array}{c}Z \text { Stat }=0.366 \\
P(T<=t)=0.714\end{array}$ \\
\hline $\begin{array}{l}\text { Product protection } \\
\text { improvement }\end{array}$ & 3.205 & 3.472 & $\begin{array}{c}Z \text { Stat }=1.266 \\
P(T<=t)=0.205\end{array}$ & 3.205 & 3.209 & $\begin{array}{c}Z \text { Stat }=0.613 \\
P(T<=t)=0.540\end{array}$ \\
\hline $\begin{array}{l}\text { Reduction of } \\
\text { packaging purchases } \\
\text { costs }\end{array}$ & 3.433 & 3.173 & $\begin{array}{c}Z \text { Stat }=1.264 \\
P(T<=t)=0.206\end{array}$ & 3.564 & 3.282 & $\begin{array}{c}Z \text { Stat }=1.322 \\
P(T<=t)=0.186\end{array}$ \\
\hline $\begin{array}{l}\text { Reduction of } \\
\text { logistics costs }\end{array}$ & 3.385 & 3.093 & $\begin{aligned} \mathrm{Z} \text { Stat } & =1.640 \\
\mathrm{P}(\mathrm{T}<=\mathrm{t}) & =0.098 *\end{aligned}$ & 3.538 & 3.215 & $\begin{array}{c}Z \text { Stat }=1.444 \\
P(T<=t)=0.149\end{array}$ \\
\hline $\begin{array}{l}\text { Reduction of } \\
\text { packing costs }\end{array}$ & 3.535 & 3.162 & $\begin{aligned} \text { Z Stat } & =1.723 \\
P(T<=t) & =0.086 *\end{aligned}$ & 3.487 & 3.376 & $\begin{array}{c}Z \text { Stat }=0.428 \\
P(T<=t)=0.669\end{array}$ \\
\hline $\begin{array}{l}\text { Improvement of } \\
\text { environmental } \\
\text { behavior }\end{array}$ & 2.889 & 2.712 & $\begin{array}{c}Z \text { Stat }=0.871 \\
P(T<=t)=0.384\end{array}$ & 3.282 & 2.714 & Z Stat $=2.288 \mathrm{P}(\mathrm{T}<=\mathrm{t})=0.022^{* *}$ \\
\hline
\end{tabular}

${ }^{*} \mathrm{P}<0.1 .{ }^{* *} \mathrm{P}<0.05$.

do not have ISO 9000, while companies that have ISO 14000 tend to benefit more from improvements in environmental behavior than those that do not have ISO 14000. In general, the difference between the two groups of companies (with and without meta-standards) does not seem very significant overall in terms of efficiency and sustainability.

\section{Discussion}

The analysis of the results in the Spanish food sector suggests that the implementation of meta-standards maybe associated, and potentially contribute, to an increased implementation of the four key aspects of "packaging logistics".

Regarding package design requirements, companies with some meta-standards in place seem to have greater integration of packaging design requirements related to production and logistic process management, and in particular, to environmental management. Interestingly, further integration with commercial, protective, or packaging purchases requirements has not been identified. The explanation could possibly be that most companies consider these last requirements as the minimum level of functionality that any packaging should satisfy.

In terms of organizational structure, we found positive differences between companies with meta-standards. Companies with these meta-standards have greater internal coordination and collaboration in packaging design between departments. In fact, this level of internal coordination matches one of the main conceptual advantages of implementing the meta-standards mentioned in the scientific literature, i.e., improving internal organizational functioning. Likewise, we found this positive impact in the coordination and collaboration with packaging manufacturers, although not with customers or distributors. The lack of difference between companies regarding downstream integration in terms of packaging design could be motivated by the content and nature of the relationship between companies and customers/distributors. In the industry studied, the price is the more important factor and short-term agreements are promoted, with little customer/distributor involvement in product design. However, insufficient coordination with distributors also negatively affects competitiveness, in terms of sales, logistic costs, and sustainability due to the packaging design decisions. 
The analysis of the implementation of measurement systems for objectively comparing different packaging alternatives is interesting. Even in the implementation of the LCA, where we have found significant differences between firms depending on the meta-standards implementation, the overall percentage of implementation is low. This lack of measurement systems to compare alternatives from an overall perspective conceals the impact of certain packaging design decisions. Thus, it is likely that companies base their design decisions solely on the direct costs (usually packaging purchases) disregarding, due to lack of visibility, the indirect costs that affect not only their own food manufacturers, but also the other companies in the chain supply. Obviously, this situation does not aid the promotion of coordination among companies, such as distributors, along the chain.

Regarding 'best practices', we have again found evidence that suggests a positive impact of the meta-standards implementation in six of the seven 'best practices' (including logistic and environmental 'best practices', and in particular, systematization practices). This latter is somewhat expected, considering the criticism and potential of the meta-standards regarding extra documentation.

While the results suggest many differences in the implementation of key aspects of packaging logistics between companies (with and without "meta-standards"), there were no major differences in terms of performance. The low implementation of measurement systems for comparing different alternatives of packaging could explain why we did not find major differences between the two groups of companies in terms of performance. All this suggests that the enhancement in the implementation of these measurement systems may lead to a greater potential for improving efficiency and sustainability in the supply chain, through a suitable packaging design. This identifies a real opportunity for improvement in companies. In addition, the enhancement of these measurement systems is consistent with the general need to develop KPls in quality and environmental management systems according to meta-standards ISO 9000 and ISO 14000.

In this context, the clearest results achieved and identified in the study are related to greater environmental awareness, which is coherent with the importance of environmental requirements in companies with ISO 14000. This situation would reinforce the idea that greater environmental awareness leads to meta-standard implementation (particularly ISO 14000), which should also lead to the deployment of actions which strengthen this commitment, with the reduction of raw materials consumption, and waste in relation to packaging, as seen in this paper.

\section{Conclusions}

In general, at least some elements of each of the key aspects of 'packaging logistics' tended to be more developed in companies with ISO 9000 or ISO 14000 than in companies without those standards. While the nature of this study is exploratory and does not allow us to establish causation, the results seem to suggest that companies that had implemented meta-standards (ISO 9000 and ISO 14000) tend to place greater focus on the key aspects of "packaging logistics' than companies that had not implemented meta-standards. This opens up new venues for future research on these important practices in the context of supply chain management. Do "meta-standards" actually facilitate the implementation of "packaging logistics' and, if so, through what mechanisms? The results of this exploratory study are a solid first step in informing managerial practice in these important areas. Future studies can build on our insights and further managerial understanding of potential synergies between two practices. Future studies can also investigate the relation between the practices in other industrial and geographical contexts as well.

In the current competitive environment, companies must deal with issues, not only in terms of new products and processes, shorter life cycles or increased commercial range, but also in terms of even lower prices, with increasingly improved quality standards and services. This situation has forced many organizations to look for a source of competitive advantage, a more sustainable supply chain management.

In the context of supply chain management, why pay attention to packaging? The answer is because packaging reproduces all the complex relationships, perspectives, and needs arising each company and between company departments, but on a smaller scale. Based on an understanding of how the packaging system works and how this is integrated in the logistics system in line with the concept of "packaging logistics", it is possible to conduct a structured and systematic search for packaging alternatives.

The results of the investigation in the Spanish food sector suggests how different companies present a greater awareness towards an appropriate packaging design from an efficient and environmental viewpoint, when quality and/or environmental management systems are developed and implemented according to ISO 9000 and ISO 14000 standards. The promotion of a suitable measurement system could have positive effects. An adequate packaging design could impact business costs, logistics improvement, and sustainable development, which could mean a better competitive position for companies. 
The proposed combined theoretical approach used in this study is novel and relevant, since the methodological treatment of the development of "packaging logistics" in literature is scarce. As such, the results should be of interest to both academia and industry, because they can aid researchers and companies in improving their global vision of product/packaging design in order to jointly increase sustainability and efficiency in the supply chain.

The main limitations of the study are related to the potential subjectivity associated with the companies' assessment in each of the items considered in research. Thus, in some of these items the authors have only considered their implementation, but not their level of deployment. This last comment can apply to the level of development of quality and environmental management systems, implemented by companies in accordance with the "meta-standards". This has prevented a further search for a selection of advanced companies with higher levels of "meta-standards" development, as outlined by Prajogo et al. (2012). Therefore, a study of Garcia-Arca et al. (2015) proposes that "packaging logistics" deployment is an evolving process with different stages that depend on the perceived importance of packaging.

\section{References}

Aarts, F. M., \& Vos, E. (2001). The impact of ISO registration on New Zeeland firms'performance: a financial perspective. The TQM Magazine, 13(3), 180-191. http://dx.doi. org/10.1108/09544780110384871.

Accorsi, R., Cascini, A., Cholette, S., Manzini, R., \& Mora, C. (2014). Economic and environmental assessment of reusable plastic containers: a food catering supply chain case study. International Journal of Production Economics, 152, 88-101. http://dx.doi.org/10.1016/j.jpe.2013.12.014.

Albrecht, S., Brandstetter, P., Beck, T., Fullana-i-Palmer, P., Grönman, K., Baitz, M., Deimling, S., Sandilands, J., \& Fischer, M. (2013). An extended life cycle analysis of packaging systems for fruit and vegetable transport in Europe. The International Journal of Life Cycle Assessment, 18(8), 1549-1567. http://dx.doi.org/10.1007/s11367-013-0590-4.

Andersen, M., \& Skjoett-Larsen, T. (2009). Corporate social responsibility in global supply chains: supply chain management. International Journal, 14(2), 77-87.

Asociación Española de Codificación Comercial. (2012). Recomendaciones AECOC para la logística: unidades de carga eficientes. Barcelona: AECOC.</report>.

Azzi, A., Battini, D., Persona, A., \& Sgarbossa, F. (2012). Packaging design: general framework and research agenda. Packaging Technology and Science, 25(8), 435-456. http:// dx.doi.org/10.1002/pts.993.

Bramklev, C. (2009). On a proposal for a generic package development process. Packaging Technology and Science, 22(3), 171-186. http://dx.doi.org/10.1002/pts.850.

Castka, P., \& Balzarova, M. A. (2008). The impact of 1509000 and ISO 14000 on standardization of social responsibilityan inside perspective. International Journal of Production
Economics, 113(1), 74-87. http://dx.doi.org/10.1016/j. ijpe.2007.02.048.

Chan, F. T. S., Chan, H. K., \& Choy, K. L. (2006). A systematic approach to manufacturing packaging logistics. International Journal of Advanced Manufacturing Technology, 29(9-10), 1088-1101. http://dx.doi.org/10.1007/s00170-005-2609-x.

Christopher, M. (2005). Logistics and Supply Chain management strategies for reducing cost and improving service (3rd ed.). London: Financial Times Pitman Publishing.

Crnkovic, J., Tayi, G. K., \& Ballou, D. P. (2008). A decisionsupport framework for exploring supply chain tradeoffs. International Journal of Production Economics, 115(1), 28-38. http://dx.doi.org/10.1016/j.ijpe.2008.04.007.

Dominic, C., Östlund, S., Buffington, J., \& Masoud, M. (2015). Towards a conceptual sustainable packaging development model: a corrugated box case study. Packaging Technology and Science, 28(5), 397-413. http://dx.doi.org/10.1002/ pts. 2113.

European Commission. (1994). Directive 94/62/EC on packaging and packaging waste. Brussels: EC.

European Commission. (2004). Directive 2004/12/EC on packaging and packaging waste. Brussels: EC.

European Organization for Packaging and the Environment. (2009). The European Shopping Baskets. Brussels: Europen and Packforsk.

Faccio, M., Gamberi, M., Pilati, F., \& Bortolini, M. (2015). Packaging strategy definition for sales kits within an assembly system. International Journal of Production Research, 53(11), 3288-3305. http://dx.doi.org/10.1080 /00207543.2014.975862.

Gamez-Alban, H. M., Soto-Cardona, C., Mejia-Argueta, C., \& Sarmiento, A. (2014). A cost-efficient method to optimize package size in emerging markets. European Journal of Operational Research, 241(3), 917-926. http://dx.doi. org/10.1016/j.ejor.2014.09.020.

García-Arca, J., \& Prado-Prado, J. C. (2008a). Packaging design model from a supply chain approach. Supply Chain Management: An International Journal, 13(5), 375-380. http://dx.doi.org/10.1108/13598540810894960.

García-Arca, J., \& Prado-Prado, J. C. (2008b). Packaging as source of competitive advantages. Universia Business Review, 17, 64-79.

García-Arca, J., Prado-Prado, J. C., \& González-Portela Garrido, A. T. (2014). Packaging logistics: promoting sustainable efficiency in supply chains. International Journal of Physical Distribution \& Logistics Management, 44(4), 325-346. http://dx.doi.org/10.1108/1JPDLM-05-2013-0112.

García-Arca, J., Prado-Prado, J. C., \& González-Portela Garrido, A. T. (2015). Drivers and stages in "Packaging Logistics": an analysis in the food sector. In P. Cortès (Ed.), Enhancing synergies in a collaborative environment (pp. 51-59). Switzerland: Springer.

García-Arca, J., Prado-Prado, J. C., \& Mejías-Sacaluga, A. (2011). The logistics development in the Spanish food and fashion sectors. Universia Business Review, 31, 42-59.

Germain, R., Claycomb, C., \& Dröge, C. (2008). Supply chain variability, organizational structure, and performance: The moderating effect of demand unpredictability. Journal of Operations Management, 26(5), 557-570. http://dx.doi. org/10.1016/j.jom.2007.10.002.

Grönman, K., Soukka, R., Järvi-Kääriäinen, T., Katajajuuri, J.-M., Kuisma, M., Koivupuro, H.-K., Ollila, M., Pitkänen, 
M., Miettinen, O., Silvenius, F., Thun, R., Wessman, H., \& Linnanen, L. (2013). Framework for sustainable food packaging design. Packaging Technology and Science, 26(4), 187-200. http://dx.doi.org/10.1002/pts.1971.

Hellström, D., \& Saghir, M. (2006). Packaging and logistics interactions in retail supply chain. Packaging Technology and Science, 20(3), 197-216. http://dx.doi.org/10.1002/ pts.754.

Heras-Saizarbitoria, 1. (2011). What happened to the ISO mania? ISO 9000, ISO 14000 and other metastandards in perspective. Universia Business Review, 29, 66-79.

International Organization for Standardization. (2015a). ISO 9001: 2015: Quality management systems: fundamentals and vocabulary. Geneva: ISO.

International Organization for Standardization. (2015b). ISO 14001: 2015: environmental management systems: requirements with guidance for use. Geneva: ISO.

Klevas, J. (2005). Organization of packaging resources at a product-developing company. International Journal of Physical Distribution \& Logistics Management, 35(2), 116-131. http://dx.doi.org/10.1108/09600030510590309.

Kye, D., Lee, J., \& Lee, K. (2013). The perceived impact of packaging logistics on the efficiency of freight transportation (EOT). International Journal of Physical Distribution \& Logistics Management, 43(8), 707-720. http://dx.doi. org/10.1108/1JPDLM-08-2011-0143.

Lee, S. G., \& Lye, S. W. (2003). Design for manual packaging. International Journal of Physical Distribution \& Logistics Management, 33(2), 163-189. http://dx.doi. org/10.1108/09600030310469162.

Lo, C. K. Y., Yeung, A. C. L., \& Cheng, T. C. E. (2009). ISO 9000 and supply chain efficiency: empirical evidence on inventory and account receivable days. International Journal of Production Economics, 118(2), 367-374. http://dx.doi. org/10.1016/j.jpe.2008.11.010.

Molina-Besch, K., \& Pålsson, H. (2014). Packaging for ecoefficient supply chains: why logistics should get involved in the packaging development process. sustainable logistics. Transport and Sustainability, 6, 137-163. http://dx.doi. org/10.1108/S2044-994120140000006006.

Mollenkopf, D., Closs, D., Twede, D., Lee, S., \& Burgess, G. (2005). Assessing the viability of reusable packaging: a relative cost approach. Journal of Business Logistics, 26(1), 169-197. http://dx.doi.org/10.1002/j.2158-1592.2005.tb00198.x.

Olsmats, C., \& Dominic, C. (2003). Packaging scorecard: a packaging performance evaluation method. Packaging Technology and Science, 16(1), 9-14. http://dx.doi. org/10.1002/pts.604.

Pålsson, H., Finnsgård, C., \& Wänström, C. (2013). Selection of packaging systems in supply chains from a sustainability perspective: the case of Volvo. Packaging Technology and Science, 26(5), 289-310. http://dx.doi.org/10.1002/pts. 1979.
Poksinska, B., Jörn Dahlgaard, J., \& Eklund, J. A. E. (2003). Implementing ISO 14000 in Sweden: motives, benefits and comparison with ISO 9000. International Journal of Quality \& Reliability Management, 20(5), 585-595. http:// dx.doi.org/10.1108/02656710310476543.

Prajogo, D., Huo, B., \& Han, Z. (2012). The effects of different aspects of 1509000 implementation on key supply chain management practices and operational performance. Supply Chain Management: An International Journal, 17(3), 306-322. http://dx.doi.org/10.1108/13598541211227135.

Saghir, M. (2004). A platform for Packaging Logistics Development: a systems approach (Dissertation). Lund University, Lund.

Saghir, M., \& Jönson, G. (2001). Packaging handling evaluation methods in the grocery retail industry. Packaging Technology and Science, 14(1), 21-29. http://dx.doi.org/10.1002/pts.523.

Seuring, S., \& Müller, M. (2008). From a literature review to a conceptual framework for sustainable supply chain management. Journal of Cleaner Production, 16(15), 16991710. http://dx.doi.org/10.1016/j.jclepro.2008.04.020.

Sohrabpour, V., Hellström, D., \& Jahre, M. (2012). Packaging in developing countries: identifying supply chain needs. Journal of Humanitarian Logistics and Supply Chain Management, 2(2), 183-205. http://dx.doi.org/10.1108/20426741211260750.

Svanes, E., Vold, M., Møller, H., Pettersen, M. K., Larsen, H., \& Hanssen, O. J. (2010). Sustainable packaging design: a holistic methodology for packaging design. Packaging Technology and Science, 23(3), 161-175.

Terziovski, M., Power, D., \& Sohal, A. S. (2003). The longitudinal effects of the ISO 9000 certification process on business performance. European Journal of Operational Research, 146(3), 580-595. http://dx.doi.org/10.1016/S03772217(02)00252-7.

Van Hoek, R., \& Chapman, P. (2006). From tinkering around the edge to enhancing revenue growth: supply chainnew product development. Supply Chain Management: An International Journal, 11(5), 385-389. http://dx.doi. org/10.1108/13598540610682390.

Verghese, K., \& Lewis, H. (2007). Environmental innovation in industrial packaging: a supply chain approach. International Journal of Production Research, 45(18-19), 4381-4401. http://dx.doi.org/10.1080/00207540701450211.

Verghese, K., Lewis, H., Lockrey, S., \& Williams, H. (2015). Packaging's role in minimizing food loss and waste across the supply chain. Packaging Technology and Science, 28(7), 603-620. http://dx.doi.org/10.1002/pts.2127.

Wever, R., \& Vogtländer, J. (2013). Eco-efficient value creation: an alternative perspective on packaging and sustainability. Packaging Technology and Science, 26(4), 229-248. http:// dx.doi.org/10.1002/pts.1978.

Williams, H., Wikström, F., \& löfgren, M. (2008). A life cycle perspective on environmental effects of customer focused packaging development. Journal of Cleaner Production, 16(7), 853-859. http://dx.doi.org/10.1016/j.jclepro.2007.05.006. 